Institute of

Public Finance
NEWSLETTER

AN OGGASIONAL PUBLIGATION OF THE INSTITUTE OF PUBLIG FINANGE

\title{
Tax reforms in EU member states
}

\author{
VJEKOSLAV BRATIĆ Institute of Public Finance
}

\begin{abstract}
At a time of an exceptionally pronounced need for consolidation of Croatian public finance and discussions about changes in the Croatian taxation system, this paper analyses, on the basis of the European Commission reports ${ }^{I}$ tax changes that in $20 \mathrm{OI}$ and in the first half of $20 \mathrm{OI} \mathrm{EU}$ Member States made to attempt to consolidate their public finances.
\end{abstract}

The financial crisis led to a significant deterioration in the condition of the public finances in most of the EU Member States, which accordingly in 2011 and in the first half of 2012 changed their fiscal policies. In the EC report of October 2012, endeavours to consolidate public finances are analysed in conjunction with the most recent taxation trends and changes in the individual members. There is a clear rise in the overall tax burden (including social security contributions) and in tax revenue, as well as an increase of existing taxes (of rates and/or bases) in many members.

\section{GHANGES IN THE EUROPEAN UNION}

From table $\mathrm{I}^{2}$ it can be seen that the largest number of countries raised rates and/or bases for consumption taxes (VAT and excises), social security contributions, and income taxes.

I European Commission, 20I2. Tax reforms in EU Member States, Tax policy challenges for economic growth and fiscal Sustainability 2012 Report, Taxation Papers, Working paper no 34. More at: http://ec.europa.eu/taxation_customs/resources/documents/taxation/gen info/economic_analysis/tax_papers/taxation_paper_34_en.pdf.

2 AT-Austria, BE-Belgium, BG-Bulgaria, CY-Cyprus, CZ-Czech R, DEGermany, DK-Denmark, EE-Estonia, EL-Greece, ES-Spain, FI-Finland, FR-France, HU-Hungary, IE-Ireland, IT-Italy, LT-Lithuania, LULuxembourg, LV-Latvia, MT-Malta, NL-Netherlands, PL-Poland, PTPortugal, RO-Romania, SE-Sweden, SI-Slovenia, SK-Slovakia, UKUnited Kingdom.
Personal income tax. In the member states, personal income taxes were most often changed by means of a temporary increase in general surcharges or solidarity contributions for high-income earners (Belgium, Greece, Italy, Cyprus, Luxembourg, Portugal and Spain), and by adopting measures for a reduction of the total tax burden, mostly by increasing work incentives for specific groups. Personal income tax accordingly became more progressive, and the average top personal income tax rate rose slightly from $37.9 \%$ to $38.1 \%{ }^{3}$

Corporate Income Tax. A large number of member countries changed the tax basis for corporate income tax by, for example, introducing tax reliefs on investment in physical capital or R\&D and by limiting the ability to deduct other items, such as operating losses. At the same time, although to a lesser extent, the long term trend towards reducing statutory and average rates (from 23.7 to $23.5 \%$ ) was continued. The highest rates were changed only in the UK, Finland, Slovenia, Greece and the Netherlands; some members increased by surcharges or levies the marginal tax rates for the largest companies only.

Social security contributions. The rates were raised in many members, and modestly reduced in Ireland and Germany only (for pension insurance).

Value added tax (VAT). In about half of the member countries, reduced and standard rates of VAT were increased (on average from 19.8 to $2 \mathrm{I} \%$ ).

3 Cyprus, by the introduction of additional tax brackets with a tax rate of $35 \%$ and temporary surcharge, recorded the largest increase (from 30 to 38.5\%). In Spain the highest personal income tax rate was increased from 43 to as much as $52 \%$. 
Table I.

Tax changes in EU countries in 2011 and the first half of 2012

\begin{tabular}{|c|c|c|c|}
\hline & & Statutory rates & Base or special regimes \\
\hline \multirow{2}{*}{$\begin{array}{l}\text { Personal } \\
\text { income tax }\end{array}$} & increase & $\begin{array}{c}\text { II countries } \\
\text { (BE, DK, CY, FI, EL, ES, IE, IT, LU*, NL, PT) }\end{array}$ & $\begin{array}{c}\text { I4 countries } \\
\text { (AT, BE, CZ*, DK, ES**, FI, FR, } \\
\text { EL, HU, IE, PL, PT, SK, UK) }\end{array}$ \\
\hline & decrease & $\begin{array}{c}4 \text { countries } \\
\text { (FI, HU, LV, NL) }\end{array}$ & $\begin{array}{c}\text { I3 countries } \\
\text { (CZ, DK, EE, FI, DE, ES, } \\
\text { HU, IE, LV, MT, NL, SE, UK) }\end{array}$ \\
\hline \multirow{2}{*}{$\begin{array}{l}\text { Corporate } \\
\text { income tax }\end{array}$} & increase & $\begin{array}{c}2 \text { countries } \\
\text { (FR, PT) }\end{array}$ & $\begin{array}{c}6 \text { countries } \\
\left(\mathrm{CZ}, \mathrm{AT}, \mathrm{BE}, \mathrm{DK}, \mathrm{ES}^{* *}, \mathrm{HU}\right)\end{array}$ \\
\hline & decrease & $\begin{array}{c}5 \text { countries } \\
\text { (UK, FI, EL, SI, NL) }\end{array}$ & $\begin{array}{c}6 \text { countries } \\
\text { (ES, HU, IT, LT, LU, UK) }\end{array}$ \\
\hline \multirow{2}{*}{$\begin{array}{l}\text { Social security } \\
\text { contributions }\end{array}$} & increase & $\begin{array}{c}\text { IO countries } \\
\text { (AT, BG, CY, FR, EL, HU, LV, PL, PT, UK) }\end{array}$ & $\begin{array}{c}2 \text { countries } \\
\text { (IE, SK) }\end{array}$ \\
\hline & decrease & $\begin{array}{c}2 \text { countries } \\
(\mathrm{DE}, \mathrm{IE})\end{array}$ & $\begin{array}{l}\text { I country } \\
\text { (CZ) }\end{array}$ \\
\hline \multirow{2}{*}{$\begin{array}{l}\text { Value } \\
\text { added tax }\end{array}$} & increase & $\begin{array}{c}\text { I4 countries } \\
\text { (PT, UK, CY, ES**, IE, HU, LV, } \\
\text { PL, SK, IT, FR, BG, EL, CZ) }\end{array}$ & 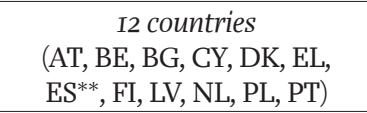 \\
\hline & decrease & ( & $\begin{array}{c}6 \text { countries } \\
\text { (CY, EL, ES, IE, LT, PL) }\end{array}$ \\
\hline \multirow[t]{2}{*}{ Excise duties } & increase & $\begin{array}{c}25 \text { countries } \\
\text { (AT, BE, BG, CY, CZ, DE, EL, ES, FI, FR, HU, IE, IT, } \\
\text { LT, LU, LV, MT, NL, PL, PT, RO, SE, SK, SI, UK) }\end{array}$ & $\begin{array}{c}4 \text { countries } \\
\text { (DK, EE, LV, PL) }\end{array}$ \\
\hline & decrease & $\begin{array}{c}\text { I country } \\
(\mathrm{SI})\end{array}$ & - \\
\hline \multirow{2}{*}{$\begin{array}{l}\text { Taxation of } \\
\text { property }\end{array}$} & increase & $\begin{array}{c}6 \text { countries } \\
\text { (CY, EL, ES, IE, PT, UK) }\end{array}$ & $\begin{array}{c}4 \text { countries } \\
\text { (CY, IT, LT, LV) }\end{array}$ \\
\hline & decrease & $\begin{array}{c}\text { I country } \\
(\mathrm{NL})\end{array}$ & - \\
\hline
\end{tabular}

* temporary increase in $201 \mathrm{II}$

** changes introduced after the cut-off date

Note: The table encompasses tax changes implemented in 2011 and the first half of 2012 including temporary but significant changes. Minor changes are not included. Tax measures are reported individually, and not consolidated on the basis of their budgetary impacts. Introduction of new taxes is listed as an increase in statutory rate. Changes in tax brackets (thresholds) are considered as base changes. Solidarity charges levied in: BE on financial income, CY on SSC, EL on high income, IT on high income, LU temporary, PT and ES all of which are classified as increases in statutory rate. PIT: In FI and NL labour income taxation has been decreased while capital income taxation has been increased.

Source: European Commission (2012a:24).

Excises duty. In most countries statutory rates were increased, above all for the environment, energy products, and for alcohol and tobacco, the only reduction (for fuel excises) being implemented in Slovenia.
Taxation of property. Only a few Member States changed taxation of property (by increasing the rates and broadening the basis) - Greece, Italy, Latvia, Lithuania, Portugal and Spain.

\section{Table 2.}

Excise duty changes in EU countries in $201 \mathrm{I}$ and 2012

\begin{tabular}{|c|c|c|c|}
\hline & & Statutory rates & Base or special regime \\
\hline \multirow{2}{*}{$\begin{array}{l}\text { Energy \& } \\
\text { environment }\end{array}$} & increase & $\begin{array}{c}\text { I7 countries } \\
\text { (AT, BG, FI, DE, EL, ES, HU, IE, IT, } \\
\text { LV, LT, MT, NL, PT, RO, SK, UK) }\end{array}$ & $\begin{array}{c}4 \text { countries } \\
\text { (DK, EE, LV, PL) }\end{array}$ \\
\hline & decrease & $\begin{array}{l}\text { I country } \\
\text { SI }\end{array}$ & - \\
\hline \multirow{2}{*}{$\begin{array}{l}\text { Tobacco, alcohol } \\
\text { and sugar etc. }\end{array}$} & increase & $\begin{array}{c}\text { 2I countries } \\
\text { (AT, BE, CY, CZ, DE, EE, ES, FI, FR, HU, LV, } \\
\text { LT, LU, NL, PL, PT, RO, SE, SK, SI, UK) }\end{array}$ & - \\
\hline & decrease & - & - \\
\hline
\end{tabular}

Source: European Commission (20I2a:29). 
Because of the announced introduction of tax on real property from April 20I3 in Croatia, a short review of changes in EU members follows:

- Greece, which in 2010 introduced a progressive real estate tax, brought in a special real estate duty on residential property, calculated on the surface area of buildings, taking into account their age and location, and is collected through electricity bills.

- Italy abolished the exemption on main residences granted by the property tax and raised the cadastral value of real estate by $60 \%$.

- Latvia doubled its progressive rates for residential buildings and broadened the base by including auxiliary buildings, parking places and houses and lands owned by the religious organisations that are not used for religious purposes.

- Lithuania broadened the basis, and an annual tax of $1 \%$ is paid on values above 290,00o euros for immovable property owned by individuals that is not used for commercial purposes (previously exempt).

- Portugal increased the minimum and the maximum rates of the real estate tax on urban property by O.I percentage point.

- In the municipal real estate tax for 2012 and 2013, Spain introduced a temporary surcharge for immovable properties with an updated cadastral value over the average value in each municipality.

\section{STHE STATE, GHALLENGES AND}

\section{RECOMMENDATIONS OF THE EUROPEAN UNION}

In spite of all the changes, the structural characteristics of the tax systems of members remain the same, and the differences in tax to GDP ratios, the total tax burden and its components are still very highly pronounced.

After several years of successive decline in the ratio of tax revenue to GDP and the lowest value in 2009, in 20I0, this ratio stabilised at about $38.4 \%$. But the ratio is very different among the members, and it is in general higher in the old than in the new member states 4 .

In addition, there is a clear long-term increase in the rate of VAT and a parallel trend to ever lower taxation of earned and unearned income.

Such trends are in line with the recent research confirming that "VAT is one of the forms of taxation with the lowest negative effect on economic growth" (more in: European Commission, 20II).

While most of the older members collect almost equal amounts of revenue from direct and indirect taxes and social security contributions, the share of direct taxes in total revenues is lower in the new members, mostly because they have adopted flat-rate systems ${ }^{5}$.

4 For example, while in 2010 the combined ratio of taxes to GDP in Lithuania was $27.1 \%$, in Denmark it was as much as $47.6 \%$.

5 The lowest ratios of direct to total taxes are in Lithuania (I7.4\%), Bulgaria (18.8\%), Slovakia (19.1\%) and Estonia (19.9\%).
Existing practices show there is a lot of room for increasing the effectiveness of VAT, particularly in the issue of the use of various exceptions and reduced rates. The report points out that the more the need for respecting the destination principle is emphasised, the more marked will be the need for a fight against VAT fraud. This requires better coordination between Member States and a simplification of existing VAT procedures. Also being examined is the economic justification for reduced VAT rates and exemptions, which crucially determine the effect of the VAT system on the economic exchange of a given state. The report states that consumption taxes are not a high quality instrument for redistribution, that reduced rates and exceptions considerably reduce budgetary revenues and enlarge the complexity of the system, all of which leads to an increase in both administrative and compliance costs in the taxation system.

The report also analyses the existing challenges and makes recommendations to members for increasing the efficiency of tax systems, particularly at a time of slower economic growth and increasing needs for fiscal consolidation. Some members could consider other measures: they can for example tax labour less, and rely more on consumption, property and ecological taxes; the base can be broadened by, for example, reviewing and/or possibly reducing various kinds of tax expenditure in direct taxation, especially in corporate income tax; improvement of the quality and efficiency of the tax governance, for example, but reducing the administrative costs of taxation and heavier reliance on e-filing of tax returns, all for the sake of reducing the unofficial economy, VAT fraud and tax evasion.

Housing taxation often relies too much on transaction taxes relative to recurrent taxes on immovable property, and members should consider a shift within property taxes.

Existing policy instruments for preserving and protecting the environment, including taxes, have to ensure the fulfilment of the agreed objectives, and energy taxes and other environmental taxes have to enable sufficient incentives for long-term reduction of emissions. Member States can use various measures at national level for improvement of the existing tax system, such as adjustment of tax rates on fossil fuels according to their carbon and energy content, the indexing of environmental taxes, a reconsideration of reduced VAT rates on energy, reduction of tax subsidies for company cars, and taxation of vehicles according to their $\mathrm{CO} 2$ emissions.

\section{GHANGES IN GROATIA}

In Croatia too in 2012 numbers of changes were made, and for 2013, additional tax amendments are planned.

Excepting the reduction of the rate for health insurance contributions, most of the other tax measures are concentrated on a greater collection of public revenue. The general VAT rate is increased, and a lower rate on some products and hospitality services is introduced, certain rights for de- 
duction of tax pre-payment are abolished, and the tax threshold for VAT registration is raised. In the corporate income tax system, the reduction in the basis by the amount of profit that goes to increase the registered capital of the company is expanded, and withholding tax on dividends is introduced for foreign legal entities at a rate of $12 \%$.

Table 3.

Tax changes in Croatia in 2012 and 2013 (planned)

\begin{tabular}{|c|c|c|c|}
\hline & & $\begin{array}{l}\text { Statutory } \\
\text { rates }\end{array}$ & Base \\
\hline \multirow{2}{*}{$\begin{array}{l}\text { Personal } \\
\text { income tax }\end{array}$} & increase & - & $\mathrm{x}$ \\
\hline & decrease & $\mathrm{x}$ & - \\
\hline \multirow{2}{*}{$\begin{array}{l}\text { Corporate } \\
\text { income tax }\end{array}$} & increase & - & - \\
\hline & decrease & - & $\mathrm{x}$ \\
\hline \multirow{2}{*}{$\begin{array}{l}\text { Social security } \\
\text { contributions }\end{array}$} & increase & - & - \\
\hline & decrease & $\mathrm{x}$ & - \\
\hline \multirow{2}{*}{$\begin{array}{l}\text { Value added } \\
\text { tax }\end{array}$} & increase & $\mathrm{x}$ & - \\
\hline & decrease & - & $\mathrm{x}$ \\
\hline \multirow{2}{*}{ Excise duties } & increase & $\mathrm{x}$ & - \\
\hline & decrease & $\mathrm{x}$ & - \\
\hline $\begin{array}{l}\text { Taxation of } \\
\text { property }\end{array}$ & \multicolumn{3}{|c|}{$\begin{array}{l}\text { the introduction of real estate tax is planned } \\
\text { from April I, 2OI3 }\end{array}$} \\
\hline
\end{tabular}

Note: the introduction of new and the harmonisation of existing, or the abolition of some, excise duties are analysed as an increase or decrease of the statutory rates.

Also stressed is an improvement in the efficiency of the collection of taxation and the work of the tax administration and greater tax discipline.

More or less all the already implemented and the proposed tax changes in Croatia keep up with the most recent trends and recommendations of the EU concerning the need to reduce the tax burden on labour and to increase tax on property and consumption. But it is an unsettled question whether such changes would at all have been needed if at the beginning of the 2000 s the persistent practice of changing the existing tax system had not started, above all, by the introduction of many reliefs, exceptions, privileges and exemptions that reduced the consistency, transparency, effectiveness and stability of the taxation system.

At the same time, for the purpose of consolidation of the Croatian public finances, much - except for the praiseworthy and welcome reduction of employers' contributions has failed to be done on the much more problematic expenditure side of the budget. For this reason the recommendations that the Institute of Public Finance has been pushing for years is topical today: "a tax policy must not be used to carry out measures of social, economic or developmental policy; instead, its basic objective and purpose are as simply, effectively and equitably as possible to collect tax revenues that are needed to cover existing outlays on public needs. After all, in Croatia it is the expenditure side of the budget that is the problem, and no changes on the revenue side, without a radical reform of expenditure, can contribute to an improvement in Croatian public finances.” (Kuliš, 2003).

\section{LITERATURA}

---, 2012. Designations and abbreviations to use. Available at: 〈http://publications.europa.eu/code/en/en-370Ioo. htm>.

European Commission, 20II. „Tax reforms in EU: Tax policy challenges for economic growth and fiscal sustainability”. Taxation Papers, Working paper, No. 28. Luxembourg: Office for Official Publications of the European Communities. Available at: <http://ec.europa.eu/taxation customs/resources/documents/taxation/gen_ info/economic_analysis/tax_papers/taxation_ paper_28_en.pdf $>$.

European Commission, 20I2a. „Tax reforms in EU Member States, Tax policy challenges for economic growth and fiscal Sustainability 2012 Report”. Taxation Papers, Working paper, No. 34. Luxembourg: Office for Official Publications of the European Communities. Available at: 〈http://ec.europa.eu/taxation_customs/resources/ documents/taxation/gen_info/economic_analysis/ tax_papers/taxation_paper_34_en.pdf .

European Commission, 20I2b. Taxation Trends in the European Union 2012. Luxembourg: Publications Office of the European Union. Available at: <http://epp.eurostat. ec.europa.eu/cache/ITY_OFFPUB/KS-DU-I2-OoI/ EN/KS-DU-I2-OOI-EN.PDF>.

European Commission, 20I2c. „European Economic Forecast”. European Economy I, Spring 20I2. European Commission: Directorate-General for Economic and Financial Affairs. Available at: 〈http://ec.europa.eu/economy_ finance/publications/european_economy/2012/ pdf/ee2oI2-I_en.pdf $>$.

Kuliš, D., 2003. „Developments in the Croatian Tax System”. Newsletter, No. I4. Available at: 〈http://www.ijf.hr/eng/ newsletter/I4.pdf>.

PwC, World Bank and IFG, 20II. Paying Taxes 2012 - The Global Picture. Available at: <http://www.doingbusiness. org/ /media/FPDKM/Doing\%2oBusiness / Documents/Special-Reports/Paying-Taxes-2012.pdf〉.

ANNEX - DETAILED TAXATION GHANGES IN GROATIA IN 2012 AND A PLAN FOR GHANGES IN 2013

\section{Personal income tax}

\section{Changes from March I, 20I2:}

- The basic personal allowance is increased from 1,800 to 2,IOo kuna a month, and for pensions from 3,200 to 3,400 kuna.

- The rates of personal income tax and tax brackets per month have been changed in the following manner: 


\begin{tabular}{ccc}
$\begin{array}{c}\text { Monthly brackets from } \\
\text { March I, 2012 (kuna) }\end{array}$ & & Rate (\%) \\
\hline up to 2.200 & I2 \\
\hline $2.200-8.800$ & 25 \\
\hline over 8.800 & 40 \\
\hline
\end{tabular}

- Personal income tax at a rate of $12 \%$ is applied to receipts from dividends and profit sharing paid out after March I, 20I2, except for those made up to December 3I, 2000, irrespective of when they were paid out. The non-taxed amount of dividend and profit sharing is 12,00o kuna a year, but it will be acknowledged only through the annual personal income tax return (the tax is calculated and paid at source). Dividends and profit shares that were made between January I, 200I and December 3I 2004 are taxed at a rate of $12 \%$.

- Differences of receipts in the case of insufficient profits for covering advance payments on dividends and profit shares are taxed at a rate of $40 \%$.

- Pensions from abroad are now taxed. The advance payment of tax on personal income from this source is calculated and paid by the taxpayer within eight days of receipt of the income.

- Taxation of pensions supplements is introduced.

- The difference between the advance payment of profit if the capital of the company is not enough to cover this advance payment is deemed income from capital.

- The obligation to keep records about calculated and paid out dividends and profits shares is repealed, as is the need to supply the Tax Administration with the prescribed report.

\section{Corporate income tax}

- The basis is reduced by the amount of profit made by which the registered capital of the company is increased. For the first time this will be applied in the procedure for making a corporate income tax return for 2012.

- Also introduced is the payment of withholding tax on dividends and shares in corporate income (profit) that are paid out from March I, 2012 to foreign legal entities at a rate of $12 \%$, except in the case of the payment of dividends and shares in corporate income made up to December 3I 2000, irrespective of when they are paid. But first of all the provisions of the avoidance of double taxation treaties have to be followed.

- Value adjustments according to value corrections of customer claims arising from March I, 2012 are allowed as expenditure if, from the maturity of the claim to the end of the tax period more than 60 days has elapsed (instead of the previous period of 120 days).

- During the determination of whether business relations between linked persons are contracted at market prices the use of the method of comparable uncontrolled prices is not privileged.

\section{Value added tax}

Changes from March I, 20I2:

- The standard VAT rate increased from 23 to $25 \%$.
- A reduced rate of VAT is introduced for supplies of edible oils and fats, baby food, water (except bottled or otherwise packaged) and white sugar from sugar cane or sugar beet.

- The right for a refund of prepayment of tax for the procurement and rental of vessels for leisure, planes, cars and other means for passenger transportation (in conjunction with certain exceptions) and for entertainment is repealed. When such goods are delivered, where the right to a refund of pre-payment of taxation cannot be claimed, they will be exempt from the payment of VAT.

\section{Changes from January I, 2013}

- The VAT registration threshold increased from 85,000 to 230,00o kuna.

- The reduced rate of VAT of IO\% is introduced for services of preparing food and restaurant services, preparing and serving non-alcoholic drinks and beverages, wine and beer in hospitality facilities.

- The threshold for three-monthly calculation of VAT is increased from 300,000 to 800,000 kuna.

- Instead of a zero rate, there is a reduced rate of $5 \%$ for bread, milk, medicines and books.

- Taxation at a reduced rate of 5\% for vessels [craft] for sport and leisure that are placed in the customs procedure of release for free sale until May 3I, 2OI3, if they have previously been in the temporary import procedure.

\section{During 2013}

- A reduction of the rate of VAT for tourist services to IO\% is announced.

\section{Obligatory contributions}

- From May I, 20I2, the contribution for health insurance was reduced from 15 to $13 \%$.

\section{Special taxes and excise duties}

- From January I, 2013, the special tax on luxury products is abolished.

- From July I, 2013 there will be a new calculation of special tax on passenger cars according to $\mathrm{CO} 2$ emission and value (which will make electric, hybrid and lowemission cars attract lower taxes and more expensive and powerful cars higher taxes). Special tax on used passenger cars is repealed.

- Harmonizing of excise duties on tobacco products and alcohol according to the minimum EU rates.

- Introduction of excise duties for all other forms of energy (electricity, gas and heating oil).

- The possibility of introducing higher excise duties on non-alcoholic beverages that have more sugar and artificial ingredients is being considered.

\section{Taxation of property}

- It is planned to introduce a real estate tax from April I, $2 \mathrm{OI} 3$. 